\title{
1993年鹿児島豪雨災害
}

岩松暉 ${ }^{*}$

\section{I. 降雨状況}

周知のように1993年は全国的に冷夏に見舞われ たが，鹿児島も例外ではなく，入梅以来長雨にた たられた。 7 月 9 日に梅雨明け宣言が出されたも ののその後も雨が止まず，気象台が「梅雨明けは はっきりしない」と撤回を発表するほどの異常降 雨であった。とくに鹿児島気象台における 7 月の 月間降雨量は $1,054.5 \mathrm{~mm}$ を記録し, 観測史上最 多となった。中でも 7 月 31 日から 8 月 7 日にかけ て鹿児島県本土中央部を中心に降った豪雨は，え びので総降水量 $1,258 \mathrm{~mm}$ を記録するなどものす ごく, 気象庁から「平成 5 年 8 月豪雨」と命名さ れた。その上, 台風までが相次いで来襲した。こ の間に鹿児島に影響を与えた台風には，7月27日 の台風 5 号, 7 月 29 日の 6 号, 8 月 $9 \sim 10$ 日の 7 号, 9 月 3 日の 13 号などがある。なお, 年間降雨 量も $4,022 \mathrm{~mm}$ と史上最多を記録している。

\section{II. 災害 概 況}

上記のような長雨により，6月中旬から 9 月下 旬にかけて県下各地で断続的に災害が激発した。 犠牲者が最初に出たのは 6 月 27 日の姶良町におけ る崖崩れ災害である。この日, 鹿児島市内でも河 川の増水で子供が 1 人㬢牲になった。 7 月 7 日に は山川町など 1 市 5 町で土砂災害があり， 7 人死 亡した。九州自動車道は開通以来初めて交通止め になった。

8 月 1 日 2 日には豪雨が県中部姶良・国分地 区や吉田町を襲い，山崩れや土石流さらには洪水 により23人の儀牲が出た。道路や鉄道が寸断され 農地も冠水した。空港のある溝辺町では時間雨量 104mm を記録したといら。

引き続いて 8 月 6 日には鹿児島地方を中心激
しい豪雨があり，鹿児島市内を流れる甲突川の上 流に当たる郡山町で時間雨量 $101 \mathrm{~mm}$ を記録して いる。夕刻には甲突川・稲荷川が汇濫し繁華街を 含む市内の広、地域が浸水し, 江戸時代に建設さ れたとして名高い五石橋のうち新上橋・武之橋の 二つが流失した。一方, 夕刻から夜半にかけて姶 良カルデラ壁に当たる国道10号線竜ケ水付近でも 豪雨があり, 各所で崖崩れ・土石流が発生, 折か ら JR 竜ヶ水駅で避難停車していた列車や, 国 道で啮滞中の自動車2,000台あまりが被災した。孤 立した人達を避難させるのに, フェリーや漁船を 使ら海路からの救助作業が深夜遅くまで行なわれ た。その頃すぐ近くの花倉病院でも土石流に見舞 われ，患者など15人が犠牲となっている。この日 の災害により鹿児島市のライフラインも壊滅的な 打撃を受け, 長期に及ぶ交通途絶・停電・断水な どにより市民生活は多大の不便を強いられた。

8 月 9 日から 10 日にかけて大型で非常に強い台 風 7 号が九州西海上を北上, 大隅半島を中心に豪 雨をもたらした。垂水市牛根の姶良カルデラ壁で は土石流が各所で発生, 5 名の犠牲者を出した。 復興仅取りかかららとする出鼻を挫かれた形であ った。

遅かった梅雨も明け, 浸水家屋にも畳が入り, 生活が軌道に乗ろらとしていた矢先の 9 月 3 日, 戦後最大級と形容された超大型の台風 13 号が薩摩 半島に上陸した。知覧町で時間雨量 $116 \mathrm{~mm}$, 加世 田市で $92 \mathrm{~mm}$ を記録し, 総雨量 $300 \mathrm{~mm}$ を超す豪 雨と強風をもたらした。金峰町では四万十層群の 山が崩れ, 避難中の人達が犠牲になった。川辺町 でも谷川を横切っていた鉄道跡の盛土が決壊, 土 石流となって下流の集落を敦った。結局この台風 
で合計35名の儀性者を出した。

また, 鹿児島市内の甲突川は再度汇濫, 加世田 市でも水害に遭った。8・6炎害の復旧に資力を使 い果たした直後だけに, 再起をあきらめる人も出 るなど, 誠に無情な台風であった。上陸時の中心 気圧が $930 \mathrm{hPa}$ と, 日本に上陸した台風では 3 番 目と言われる大型台風だけに強風による家屋の被 害も著しいものがあり，住家だけで一部損壊を含 めると 27,000 戸を超した。

9 月 20 日には午後 8 時頃, 日置郡日吉町の花崗 岩の山で地すべりが発生, 2 世帯 5 人が生き埋め になった。 3 人は助け出されたものの母子が犠牲 になった。この日の雨量は僅か $13 \mathrm{~mm}$ で, 地元で は全く警戒していなかったという。しかし，台風 13号の時, 道路擁壁が倒壊したり, 斜面裾部での 涌水の増加, 井戸水の涸渇など前兆と思われる現 象があったと言われ，この間の長雨により少しず つすべっていたと考えられる。

以上, 3 力月に及ぶ長期間, 鹿児島県は繰り返 し繰り返し激甚な災害を被り，この間の被害の合 計は，県災害対策本部の集計によると，死者行方 不明者121名, 重軽傷者348名, 被害総額3,000億 円にも上ったという。この被害額には JR など私 企業の損害額は加えられていないから，すべてを 合わせると天文学的数字になるであろう。

\section{III. 斜面崩壊の特徵}

200〜 300年に 1 度といわれる異常な長雨と豪雨 により, 県下各地に斜面崩壊が多発したが, 地面 が長雨によりたっぷりと水を含んでいたことに起 因して, 以下のような従来の崩壊事例と異なる点 がみられた。すなわち, (1)鹿児島の災害というと シラス災害が著名であるが，これだけの雨が降る とシラス斜面だけでなく，基岩の地質の如何にか かわらずどこでも発生した。例えば, 四万十層群・ 花崗岩・第四紀堆積岩・安山岩・溶結凝灰岩等々 さまざであった。マスコミなどでシラスの特殊 性だけを強調し過ぎて, 逆に他の地質のところに 住んでいる人達に誤った安心感を植えつけてしま った点が問題として挙げられる。(2)単なる風化表 土層の表層すべりばかりでなく, 地下水の突出に よる崖錐堆積物の崩壊が多発した。(3)溶結凝灰岩 などの垂直な崖では転倒崩壊（トップリング）も
見られた。(4)崩壊土砂の流動性が高かったため到 達距離が異常に長く被害を大きくした。(5)また姶 良ニュータウンにおけるシラス表層すべりのよう に，表層すべりにしても，谷型斜面のような集水 地形構造のところだけでなく，凸状斜面であろう と平衡斜面であろうと，いたるところで発生した。 紙幅の関係もあるので 1 箇所で一番多くの被害 を出した花倉病院の例を 1 例紹介する。ここは更 新世花倉層の凝灰質砂岩・シルト岩からなる。ほ ぼ水平であるが，心持ち流れ盤をなす。これを溶 結凝灰岩の岩塊や薩摩降下軽石を含む崖錐堆積物 が被っている。崩壊は崖錐とシルト岩との境で発 生した。崖錐はこの部分で $1 \sim 2 \mathrm{~m}$ の厚さがあ り，下底部に涌水が認められる。この湧水が引き 金となって崩壊が発生したものと思われる。崩土 量自体はそれほど多くなく，ごく小規模な表層崩 壊であったが，不幸にして崩土が水路を破壊した ため，その水を得て流動化し土石流と化したので ある。なお崩壊地点の冠頂部には古い崩壊地形が 残存しており，かつても崩壊があったことが認め られる。
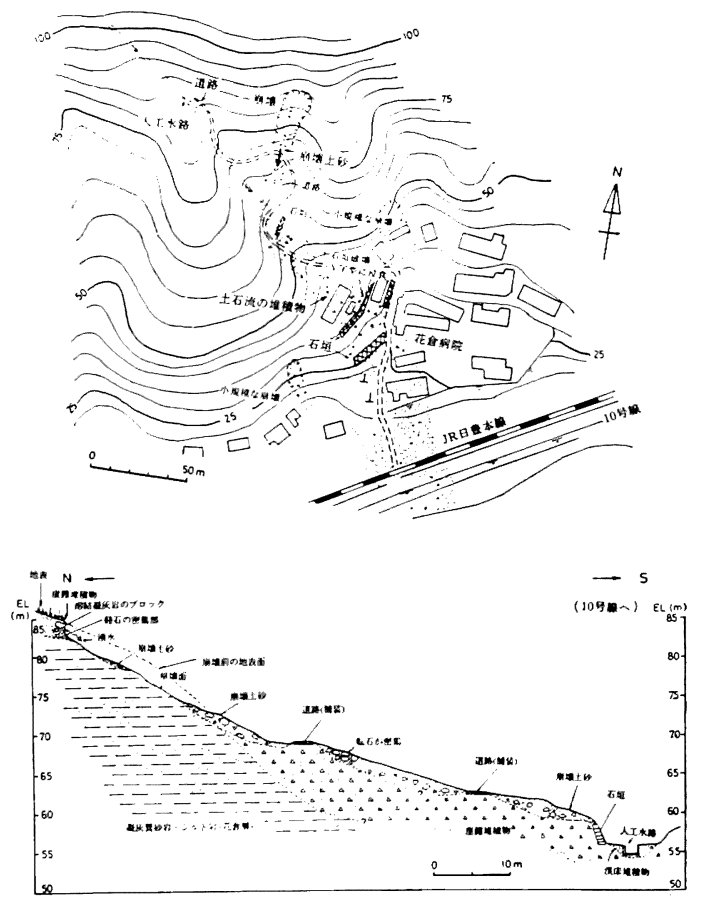

花倉崩壊地点の平面図と地質断面図 (横田・岩松, 1994) 